\title{
CHRZEŚCIJAŃSKA FORMACJA MORALNA WZORCEM ETYCZNYM DLA WSPÓŁCZESNEGO CZŁOWIEKA
}

DOI: http://dx.doi.org/10.12775/TiCz.2017.003

\section{WPROWADZENIE}

Jednym z najważniejszych wymiarów odpowiedzialności człowieka za rozwój samego siebie jest chrześcijańska formacja moralna. Integralny rozwój osoby ludzkiej domaga się bowiem jasnej orientacji moralnej w życiu, wyraźnego sprecyzowania celu i sensu egzystencji oraz ustalenia właściwej postawy, w której człowiek odnaleźć może swą rzeczywistą pełnię ${ }^{1}$. Niestety, w dzisiejszym świecie ten aspekt rozwoju człowieka jest wyraźnie lekceważony lub nawet zupełnie pomijany.

W niniejszej refleksji naukowej zostanie ukazana konieczność chrześcijańskiej formacji moralnej człowieka i jej konkretne problemy,

* Ks. dr hab. Marek Kluz, prof. UPJPII - prodziekan Wydziału Teologicznego Sekcja w Tarnowie Uniwersytetu Papieskiego Jana Pawła II w Krakowie, kierownik Podyplomowych Studiów z Etyki na WTST, adiunkt z habilitacją przy Katedrze Teologii Moralnej i Duchowości WTST (mkluz@op.pl).

1 Por. T. Borutka, Stała formacja obowiązkiem każdego człowieka wierzącego, „Polonia Sacra” 2 (1999) 4, s. 15-31. 
a także zostaną przedstawione - poprzez odwołanie się do antropologii chrześcijańskiej - fundamentalne aspekty tejże formacji. Nie można bowiem mówić o prawdziwej formacji moralnej bez ukazania podstaw antropologicznych całego procesu. To właśnie przyjęta koncepcja człowieka staje się źródłem celów i zadań, które stawia sobie chrześcijańska formacja moralna.

Celem zaś chrześcijańskiej formacji moralnej jest ukształtowanie takiego człowieka, który w swoich wyborach życiowych zdobędzie umiejętność rozróżniana dobra od zła, osiągnie zdolność dojrzałego i odpowiedzialnego działania, posiądzie umiejętność dialogu i współpracy oraz będzie się troszczył o dobro wspólne i podstawowe wartości.

\section{POTRZEBA NOWEJ REFLEKSJI NAD ROZWOJEM I JAKOŚCIĄ CHRZEŚCIJAŃSKIEJ FORMACJI MORALNEJ}

Jakość życia ludzkiego, zarówno w wymiarze indywidualnym, jak i społecznym uwarunkowana jest przede wszystkim jakością formacji moralnej. Formacja ta decyduje również o kierunku rozwoju ludzkości, czyli w dużej mierze określa przyszłość rodziny ludzkiej. Trudno się więc dziwić, że kwestie formacyjne stanowią przedmiot zainteresowania specjalistów z wielu dziedzin wiedzy, m.in. pedagogów, psychologów, socjologów i teologów. Nierzadko również różni działacze społeczni, a także politycy, interesują się treścią, kierunkami i formami formacji moralnej człowieka. Jakkolwiek funkcjonuje $\mathrm{w}$ tej dziedzinie wiele różnych teorii, problem formacji moralnej pozostaje wciąż kwestią otwartą. Także dlatego, że formacja człowieka w każdym pokoleniu musi niejako aktualizować się na nowo, tzn. być otwartą na nowe inspiracje i praktyczne rozwiązania. Stąd szczególnie w obecnym świecie, „lansującym wzorce wychowawcze opatrywane mianem 'neutralnych aksjologicznie' i niosącym niejednokrotnie zamierzoną destrukcję moralną fundamentów życia społecznego i indywidualnego" ${ }^{2}$, istnieje pilna potrzeba ukazania takiego modelu for-

${ }^{2}$ J. Życiński, Wiara chrześcijańska $w$ dialogu $z$ kulturq współczesna według Jana Pawła II, „Ethos” 11 (1998) 1-2, s. 139. 
macji moralnej człowieka, który nie ulegałby łatwej dewaluacji, ale miał moc opierania się dehumanizacyjnym naciskom współczesnej cywilizacji³ Problem pogłębia się przez to, że chrześcijański etos bywa dziś różnorako deprecjonowany, także w rzeczywistości polskiej. Wierzący w Chrystusa często opowiadają się za takimi wyborami moralnymi, które są sprzeczne z Jego nauką. W konsekwencji człowiek w danym momencie może wybrać to, co przyniesie mu największą korzyść materialną lub zaspokoi egoistyczną doraźną potrzebę; a taki wybór - w istocie etycznie destrukcyjny dla tegoż człowieka - może dokonać się nawet kosztem drugiej osoby czy społeczności, w której on żyje. Postawa taka rzutuje również na odniesienie się do Boga oraz, co oczywiste, deformuje całość życia moralnego istoty ludzkiej. Chrześcijanie często deformują i marnują swoje życie przez to, że nie umieją czy też nie chcą przyjąć jasnej, płynącej z Ewangelii, orientacji moralnej. Niewłaściwie akomodują się do „spoganiałego” świata i w praktyce egzystują tak, jakby Boga nie było. Na to niepokojące zjawisko zwrócił uwagę Jana Paweł II w adhortacji apostolskiej Ecclesia in Europa: „Europejska kultura sprawia wrażenie 'milczącej apostazji' człowieka sytego, który żyje tak, jakby Bóg nie istniał [...]. Do kultury tej należy też coraz bardziej rozpowszechniony agnostycyzm religijny, związany z pogłębiającym się relatywizmem moralnym i prawnym, który jest następstwem zagubienia prawdy o człowieku jako fundamencie niezbywalnych praw każdego"4.

We współczesnych najbardziej rozwiniętych cywilizacjach z chrześcijańskim rodowodem (Europa, Ameryka Północna) dostrzec można przejawy zorganizowanego zła, dążącego do zniszczenia religii, moralności i samej cywilizacji wyrosłej z judeochrześcijańskich korzeni. Pokłosiem takich negatywnych trendów jest samotność, zagubienie sensu życia, bezradność wobec zadań życiowych oraz rozprzestrzenianie się różnorakich uzależnień. W świecie, który skazał Boga na banicję, poszerza się krąg osób negujących sens istnienia człowieka i świata. Ludzie odrzucają normy moralne, wybierają antywartości, absolutyzują wolność i amputują wertykalny wymiar rzeczywistości, również moralnej5.

${ }^{3}$ Por. M. Nowicka-Kozioł, Odpowiedzialność w świecie alternatyw współczesnego humanizmu, Warszawa 1997, s. 10.

4 Jan Paweł II, Adhortacja apostolska „Ecclesia in Europa”, Wrocław 2003, nr 9.

5 Por. tamże, nr 7-9. 
Postępujące procesy laicyzacyjne i deprecjonujące chrześcijaństwo skutkują także różnego rodzaju wypaczeniami w wielu współczesnych koncepcjach pedagogiczno-wychowawczych, o których mówi się coraz głośniej, że są „w kryzysie i na rozdrożu”. Wobec zanegowania wiary w moc oddziaływań wychowawczych kształtujących życie moralne człowieka, palącą potrzebą chwili staje się pogłębiona refleksja nad człowiekiem widzianym integralnie, to jest również w transcendentalnym wymiarze jego osobowego bytu; potrzeba refleksji nad rozwojem i formacją moralną istoty ludzkiej. Niewątpliwie taką szansę niesie chrześcijańska formacja moralna, na którą składają się sprawdzone przez wieki ideały, zasady i wartości. Ich niekwestionowana wartość i uniwersalny charakter wynikają choćby z tego, że chrześcijańskie tzn. powszechne podstawy formacyjne odznaczają się głębokim realizmem w postrzeganiu natury ludzkiej, zranionej przez grzech, ale odkupionej łaską i powołanej ku świętości.

Wyłania się więc konieczność gruntownego i szczegółowego opracowania chrześcijańskich podstaw formacji moralnej człowieka, formacji, która będzie autentycznym wzorcem etycznym dla współczesnego, często zagubionego człowieka. Zgodnie z teologicznym rozumieniem termin „formacja” (łac. formatio) oznacza „kształtowanie”, „wychowanie”. Dlatego też tych pojęć w wielu publikacjach - podobnie też i w dokumentach Kościoła i w języku teologicznym - często używa się zamiennie. Wydaje się jednak, że termin „formacja”, najlepiej oddaje istotę rzeczy. Formacja oznacza wywieranie trwałych wpływów przez osobę, grupę, instytucje na osobowość drugiego człowieka w celu ukształtowania w nim, zgodnie z odpowiednim modelem, psychicznych struktur poznawczo-oceniających, systemu przekonań i wartości oraz wytworzenia wypływających $\mathrm{z}$ nich umiejętnych działań w określonym kierunku $\mathrm{ku}^{6}$. W procesie formacyjnym odbiorca jest podmiotem aktywnym. On sam najlepiej ocenia potrzeby własnego rozwoju i nadaje mu indywidualny charakter. Można więc mówić o swoistej autoformacji. Zadaniem formacji jest wspomagać samorozwój osoby, ułatwiać autorealizację i dostarczać obiektywnych wzorów do samooceny. Formacja ma ze swej istoty charakter integralny,

${ }^{6}$ Por. Z. Chlewiński, Formacja, w: Encyklopedia katolicka, t. 5, red. L. Bieńkowski, P. Hemperek, S. Kamiński i in., Lublin 1989, kol. 389. 
gdyż chodzi w niej o pełny i wszechstronny rozwój człowieka. Co warte podkreślenia, istotną częścią integralnej formacji człowieka jest zawsze formacja moralna ${ }^{7}$.

Wyrażenie „formacja moralna” wskazuje na to, że chodzi o formację, która stawia sobie za cel ukształtowanie człowieka jako odpowiedzialnego podmiotu moralnego. Warunkiem pozytywnej oceny danej formacji moralnej jest traktowanie przez nią osoby jako podmiotu, uwzględnienie godności człowieka oraz ukierunkowanie tejże formacji na cel, jakim jest osiągnięcie doskonałości moralnej. Formacja moralna jest potrzebna człowiekowi, bo nie rodzi się on gotowy i mając podstawowe odczucie wybierania dobra a unikania zła, musi się uczyć co jest dobre, a co jest złe.

Naczelną ideą chrześcijańskiego system formacji moralnej człowieka jest chrystocentryzm. Chrystus - jak uczy Jan Paweł II w encyklice Veritatis splendor - jest dla człowieka „'drogą, prawdą i życiem'. Dlatego ostatecznej odpowiedzi na każde pytanie człowieka, zwłaszcza na jego pytania religijne i moralne, udziela jedynie Jezus Chrystus" Chrystusa i Jego nauki moralnej to warunek sine qua non adekwatności i skuteczności całego procesu formacji. Przyjęcie Chrystusa daje stabilny fundament i pozwala odnaleźć właściwą motywację do chrześcijańskiego życia moralnego ${ }^{9}$. Prawdę tę wielokrotnie i na wiele sposobów ukazywał w swoim nauczaniu Jan Paweł II oraz Benedykt XVI. Czyni tak również obecny papież Franciszek.

Formacja moralna człowieka urzeczywistnia się przede wszystkim przez trzy główne wspólnoty z natury swej formujące: rodzinę, szkołę i Kościół. Jan Paweł II w swoim nauczaniu wskazywał na nieodzowność współdziałania rodziny, szkoły i Kościoła w procesie formacji moralnej. Tym, co wyznacza główne linie tak widzianej koncepcji formacji moralnej człowieka jest świadomość wychowawcza rodziny, szkoły i Kościoła, a także udział osoby w wychowaniu poprzez samowychowanie. Oczywiście nie znaczy to, że należy zupełnie pomijać inne instytucje wspomagające proces wychowania osoby ludzkiej.

7 Por. S. Mojek, Formacja moralna, w: Jan Paweł II, Encyklopedia Nauczania Moralnego, red. J. Nagórny, K. Jeżyna, Radom 2005, s. 205.

8 Jan Paweł II, Encyklika „Veritatis splendor”, Wrocław 1993, nr 2 (dalej: VS).

9 Por. szerzej: P. Góralczyk, Jezus Chrystus norma moralności chrześcijańskiej, „Communio” 27 (1997) 2, s. 101-113. 
Pierwszym i niezastąpionym środowiskiem formacji moralnej jest rodzina ${ }^{10}$. Tworzący Kościół domowy rodzice już sakramencie bierzmowania, a następnie w sakramencie małżeństwa otrzymali łaskę i zadanie formacji, ukierunkowanej na pełny rozwój ludzki i chrześcijański. Im większa jest rodzinna świadomość bycia Kościołem domowym, tym lepiej uformowani będą członkowie rodziny do realizacji swego powołania w budowaniu królestwa Bożego.

Dobra szkoła jest, drugim po rodzinie, niezwykle istotnym miejscem moralnej formacji ${ }^{11}$. Szkoła oddziałuje na rodzinę jako wspólnotę mającą zasadnicze znaczenie, dopełniając wykonywane przez nią zadania, jednak w żadnej mierze nie zastępując jej. Szkoła jest powołana, by każdemu człowiekowi dać szansę kształtowania własnej osobowości, swego życia intelektualnego, ale również moralnego i duchowego, co jest niezbędnym warunkiem twórczego włączenia się jednostki w funkcjonowanie obywatelskiego społeczeństwa. Dlatego też każda szkolna placówka powinna być dla wszystkich - nauczycieli i uczniów - autentyczną wspólnotą, na kształt wielkiej rodziny wychowawczej, w której każdy spotyka się z szacunkiem niezależnie od swoich zdolności i możliwości intelektualnych ${ }^{12}$. Szkoła, oprócz animowania rozwoju intelektualnego, kulturowego, społecznego i zawodowego człowieka, winna dostarczać odpowiedniego zasobu wartości i zasad moralnych oraz autentycznie stymulować harmonijny rozwój osoby ludzkiej ${ }^{13}$. Aby mogła spełniać swoją funkcję formacyjną,

${ }^{10}$ Por. np.: Sobór Watykański II, Deklaracja o wychowaniu chrześcijańskim „Gravissimum educationis”, w: Sobór Watykański II, Konstytucje. Dekrety. Deklaracje, Poznań 1968, nr 1-3; Jan Paweł II, Adhortacja apostolska „Familiaris consortio”, Częstochowa 1991, nr 36-40 (dalej: FC); Jan Paweł II, List do Rodzin, Wrocław 1994, nr 16 (dalej: LdR); Benedykt XVI, Rodzina, szkoła, parafia - miejsca formacji chrześcijanina. Homilia podczas nieszporów (Monachium - 10 września 2006), „Sprawy Rodziny” 1 (2007), s. 13; Katechizm Kościoła Katolickiego, Poznań 1994, nr 2221-2229 (dalej: KKK); R. Adrjanek, Wychowanie moralne dzieci i młodzieży jako zadanie rodziny, szkoły i Kościoła w świetle nauczania Jana Pawła II, „Sosnowieckie Studia Teologiczne” 7 (2005), s. 10-14.

${ }_{11}$ Por. np.: FC 40; Z. Olek-Redlarska, Edukacja moralna - szansą?, „Życie Szkoły" 2 (1999), s. 138-139.

12 Por. Jan Paweł II, Wychowanie człowieka do wartości moralnych. Przemówienie do uczestników XIV Światowego Kongresu Szkół Katolickich (Rzym - 5 marca 1994), „L'Osservatore Romano” (wyd. pol.) 15 (1994) 5, s. 16-17.

${ }_{13}$ Por. Jan Paweł II, Wychowanie młodego pokolenia zadaniem wszystkich. 
musi istnieć odpowiednie prawodawstwo cywilne, zaś wszyscy tworzący środowisko szkolne powinni posiadać właściwe rozumienia wolności w dziedzinie wychowania.

Do współpracy w dziele formacji moralnej wezwany jest także Kościół ${ }^{14}$. Kościół jest najlepszą Matką a każda dobra matka wychowuje. Chrześcijanin należący do kościelnej rodziny dzieci Bożych, jest formowany przez Kościół i w Kościele, we wzajemnej komunii wszystkich jego członków: duchownych i świeckich. Uświadamia to Jan Paweł II: „Mniej doskonali [...] są noszeni i formowani jak w matczynym łonie, przez bardziej doskonałych, ażeby byli poczęci i zrodzeni dla wielkości i piękna cnót"15. Formacja moralna jest dziełem całego Kościoła powszechnego. Pierwszym wychowawcą jest papież „utwierdzający braci w wierze" poprzez swe nauczanie Namiestnika Chrystusa. W Kościołach lokalnych troska o formację duchownych i świeckich spoczywa na biskupie diecezjalnym, który głosząc słowo Boże, sprawując Eucharystię i inne sakramenty czuwa nad rozwojem chrześcijańskiego życia moralnego i dba o jego właściwy kierunek. Podobna formacyjna rola przypada parafii. Tutaj najłatwiej nawiązać interpersonalny kontakt oraz wspomagać siebie nawzajem $\mathrm{w}$ rozwoju moralnym nie tylko przez przepowiadanie, katechizację i celebrację, ale również poprzez wspólny obchód różnych ważnych dla danej wspólnoty wydarzeń, oraz rozliczne formy kierownictwa duchowego.

\section{FUNDAMENTALNE PŁASZCZYZNY CHRZEŚCIJAŃSKIEJ FORMACJI MORALNEJ}

W integralnym procesie rozwoju moralnego człowieka podstawową rolę pełni formacja ludzka. Stawia sobie ona za cel ukształtowanie

Przemówienie do uczestników europejskiego sympozjum na temat: „Wyzwania edukacji” (Rzym - 3 lipca 2004), „L'Osservatore Romano” (wyd. pol.) 25 (2004) 11-12, s. 22-23.

${ }_{14}$ Por. np.: FC 40; LdR 16; Benedykt XVI, Rodzina, szkoła, parafia - miejsca formacji chrześcijanina, s. 14; R. Adrjanek, Wychowanie moralne dzieci i młodzieży jako zadanie rodziny, szkoły i Kościoła, s. 19-24.

15 Por. Jan Paweł II, Adhortacja apostolska „Christifideles laici”, Wrocław 1989, nr 61. 
człowieka jako odpowiedzialnego podmiotu moralnego. Formacja ludzka powinna więc rozwijać zespół ludzkich wartości, bez których nie można osiągnąć silnej osobowości. Praca formacyjna powinna być prowadzona w duchu takich istotnych wartości jak: godność człowieka, sumienie, płciowość, prawda, wolność i odpowiedzialność. Ze względu na kryzys owych wartości w świecie współczesnym, istotnym wymiarem procesu formacyjnego powinno być demaskowanie błędnych przekonań i postaw w odniesieniu do świata wartości i pomaganie człowiekowi w odkrywaniu prawdziwego znaczenia istotnych wartości życia ludzkiego.

Centralną rolę $\mathrm{w}$ dziedzinie formacji ludzkiej odgrywa godność osobowa, ogniskująca w pewien sposób wszystkie wymiary życia i działania człowieka. Godność ludzka jest wartością podstawową, a jej źródłem jest fakt stworzenia człowieka na obraz i podobieństwo Boże. Podobieństwu do Boga odpowiada zatem obowiązek prowadzenia takiego sposobu życia, który człowieka najbardziej zbliża do Boga, obowiązek naśladowania Boga ${ }^{16}$. W praktyce oznacza to, że człowiek obdarzony przez Boga rozumem i wolnością „powinien - jak mówił papież Benedykt XVI - żyć prawdziwe po ludzku, prawdziwie humanitarnie; powinien mieć humanistyczne wykształcenie, formację, ludzkie cnoty; powinien rozwijać swoją inteligencję; kształtować swoją wolę; swoje skłonności, swoje uczucia; powinien być naprawdę człowiekiem - człowiekiem według woli Stwórcy, Odkupiciela"17. Prawda o godności osoby ludzkiej ma więc istotny wpływ na właściwy kształt życia moralnego człowieka.

$\mathrm{Na}$ tak pełne odczytanie swej godności pozwala człowiekowi sumienie moralne. Nie znaczy to jednak, jakoby można było zawsze i bez ryzyka błędu iść za jego głosem. Stąd wynika zadanie formacji sumienia, które jest zasadniczym celem wychowania moralnego człowieka ${ }^{18}$. Aby

16 Por. KKK 1703-1707. Por. także: I. Mroczkowski, Chrześcijańska koncepcja człowieka i jego działania, w: Być chrześcijaninem dziś. Teologia dla szkół średnich, red. M. Rusecki, Lublin 1992, s. 284; E. Reszczyńska, Biblijne podstawy godności osoby ludzkiej, w: Wyznawać wiarę dzisiaj. Katecheza dorosłych na podstawie Katechizmu Kościoła Katolickiego, red. S. Łabendowicz, Sandomierz 1999, s. 462-464.

${ }_{17}$ Benedykt XVI, Uczmy się przeżywać z Chrystusem cierpienia życia duszpasterskiego. „Lectio divina” dla duchowieństwa diecezji rzymskiej (Watykan - 18 lutego 2010), „L'Osservatore Romano” (wyd. pol.) 31 (2010) 5, s. 25.

${ }_{18}$ Por. VS 64. Por. także: A. Derdziuk, Formacja moralna a formacja sumienia, 
jednak osądy sumienia były prawdziwe, nie wystarczy znać ogólne prawo Boże. Potrzebna jest wewnętrzna dyscyplina człowieka, współbrzmiąca z prawdziwym dobrem. Praca wychowawcza ściśle związana $\mathrm{z}$ formowaniem sumienia, pomaga człowiekowi stawać się coraz bardziej człowiekiem, kształtuje w nim coraz większy stosunek do życia, wprowadza go bardziej w prawdę, wychowuje do prawidłowych relacji międzyosobowych i pozwala mu też lepiej odczytać ludzką płciowość ${ }^{19}$.

Płciowość jest prawdziwym bogactwem osoby ludzkiej, nadającym istotne znamię wszystkim relacjom o charakterze osobowym; także w relacji do Boga $^{20}$. Dlatego „Kościół uważa za swoją bardzo naglącą i niezastąpioną misję ukazywania płciowości jako wartości i zadania całej osoby ludzkiej - mężczyzny i kobiety - stworzonych na obraz Boga"21. Ta nagląca potrzeba jest podyktowana tym, że współczesna kultura poważnie zniekształca prawdziwie znaczenie ludzkiej płciowości, gdyż pozbawia ją zasadniczego odniesienia do osoby i odrywa ją od norm moralnych ${ }^{22}$. Ze względu na związek istniejący między wymiarem płciowym osoby a jej wartościami etycznymi, solidna formacja ma doprowadzić człowieka do znajomości i konieczności kierowania się zasadami moralnymi w dziedzinie ludzkiej płciowości ${ }^{23}$.

w: Formacja moralna, formacja sumienia, red. J. Nagórny, T. Zadykowicz, Lublin 2006, s. 13-32; J. Orzeszyna, Kształtowanie sumienia podstawowym obowiąziem człowieka, „Sosnowieckie Studia Teologiczne” 4 (1999), s. 59-74.

19 Por. M. Jakubiec, Rola rodziny w ksztattowaniu sumienia dziecka, w: Wychowanie $w$ rodzinie, red. F. Adamski, Kraków 2010, s. 164-169; M. Wolicki, Wychowanie sumienia jako najistotniejszy element wychowania moralnego, w: Wychowanie chrześcijańskie. Między tradycją a wspótczesnością, red. A. Rynio, Lublin 2007, s. 393-405.

${ }^{20}$ Por. Papieska Rada ds. Rodziny, Ludzka płciowość: prawda i znaczenie. Wskazania dla wychowania $w$ rodzinie, Watykan 1995, nr 46.

21 FC 32.

${ }^{22}$ Por. K. Glombik, Współczesny kontekst społeczno-kulturowy wychowania seksualnego. Próba diagnozy, „Family Forum” 1 (2011), s. 161-166. Por. także: M. Kwiek, Błędy w wychowaniu płciowym człowieka, w: Wychowanie do czystości - utopia czy zadanie red. J. Kochel, Opole 2011, s. 145-152.

${ }^{23}$ Por. J. S. Szymczak, Problematyka wychowania ludzkiej płciowości w nauczaniu Jana Pawła II, „Studia nad Rodziną” 1 (1997) 1, s. 55-61; A. Bławat, Formacja seksualna, w: Słownik małżeństwa i rodziny, red. E. Ozorowski, Warszawa-Łomianki 1999, s. 150. 
Formacja ludzka - oprócz poczucia godności, sumienia i płciowości - obejmuje także takie wartości jak prawdę i wolność ${ }^{24}$. Człowiek ze swej natury - jako istota rozumna i wolna - może i powinien osobistym wysiłkiem i przy wsparciu wychowawców docierać do prawdy, pojmować ją i objawiać innym ${ }^{25}$. Prawda nadaje zasadniczy kierunek życiu człowieka. Człowiek posłuszny prawdzie, kierujący się w życiu prawdą, jest wierny samemu sobie. Najlepszym nauczycielem prawdy, ale też i samą Prawdą jest Jezus Chrystus ${ }^{26}$. Chrystus objawia człowiekowi, że otwarcie się na prawdę, szczere przyjęcie prawdy jest podstawowym warunkiem wolności. Prawda jest wzorem i probierzem wolności. Dojrzałość ludzka wymaga zatem ,autentycznej i solidnej formacji do wolności, która polega na konsekwentnym i szczerym posłuszeństwie wobec 'prawdy' własnego istnienia, wobec sensu własnego życia, czyli bezinteresownego daru z siebie samego' jako drogi i najważniejszej treści prawdziwej samorealizacji”'27. Autentyczna wolność nie jest nigdy wolnością dla siebie, ale jest ukierunkowana na miłość, a więc na solidarność z innymi i potwierdza się najpełniej w służbie dla innych ${ }^{28}$. Prowadzi to do ścisłego związku wolności z odpowiedzialnością. Nie można prawdziwie człowieka uczynić wolnym bez równoczesnego obudzenia w nim większej świadomości odpowiedzialności za swoje własne życie i za życie innych ludzi. Wolność zatem idzie zawsze $\mathrm{w}$ parze $\mathrm{z}$ odpowiedzialnością ${ }^{29}$.

Wszystkim powyższym wartościom pełny sens nadał Jezus Chrystus. Zarówno w swoim nauczaniu jak i postępowaniu ukazał ich praw-

${ }^{24}$ Por. A. Maryniarczyk, Wolność a prawda, „Człowiek w Kulturze” 9 (1997), s. $64-67$.

25 Por. Jan Paweł II, Odpowiedzialność za prawdę poznawana i przekazywaną. Przemówienie do przedstawicieli świata nauki (KUL - 9 czerwca 1987), w: tenże, Nauczanie społeczne. Trzeci pielgrzymka do Polski 8-14 czerwca 1987, Warszawa 1988, s. 30-31. Por. także: W. Starnawski, Doświadczenie prawdy i jego znaczenie w wychowaniu, w: Wychowanie chrześcijańskie, s. 317-330.

${ }^{26}$ Por. Franciszek, Encyklika „Lumen fidei”, Kraków 2013, nr 30 (dalej: LF).

27 Jan Paweł II, Adhortacja apostolska „Pastores dabo vobis”, Wrocław 1995, nr 44 .

${ }^{28}$ Por. J. Orzeszyna, Moralny aspekt ludzkiej wolności, „Analecta Cracoviensia” 33 (2001), s. 182-186.

${ }^{29}$ Por. B. Lulek, Wolność i odpowiedzialność w procesie wychowania. Szanse i zagrożenia, w: Wolność i wychowanie, red. M. Urbańska, Tarnów 2011, s. 89-106. 
dziwą wielkość. Dlatego w prowadzonej działalności formacyjnej należy dążyć do osiągnięcia w pełni dojrzałości ludzkiej na wzór ideału wychowawczego, którym jest Jezus Chrystus ${ }^{30}$. Praca formacyjna powinna być prowadzona zgodnie z zasadami wychowania katolickiego, którego priorytety wskazuje nauczanie Kościoła.

Program chrześcijańskiej formacji moralnej obejmuje - oprócz kształtowania wymiaru ludzkiego - także wiele innych ważnych płaszczyzn życia człowieka. W osiąganiu dojrzałości moralnej fundamentalną rolę pełni przed wszystkim formacja do życia w cnocie. Dzięki cnotom życie ludzkie nie tylko osiąga pełnię człowieczeństwa, lecz także staje się ono prawdziwym przebóstwieniem człowieka. Wszystkie sprawności moralne właściwie ukształtowane w człowieku, przyczyniają się więc do jego moralnej doskonałości ${ }^{31}$.

Fundamentalną rolę na drodze wzrostu życia moralnego człowieka pełni cnota religijności. Cnota ta obejmuje różne czynności odnoszące się do oddawania Bogu należnej czci. Cześć oddawana Bogu znajduje swój wyraz między innymi w takich aktach kultu jak: modlitwa, świętowanie niedzieli, wpatrywanie się w Maryję i ludzi świętych, pielgrzymowanie, praktykowanie rad ewangelicznych, składanie przyrzeczeń i ślubów oraz innych czynnościach religijnych przeznaczonych w sposób szczególny celom kultu. Człowiek jako istota religijna w formowaniu swojego życia chrześcijańskiego koniecznie potrzebuje tego rodzaju aktów kultu religijnego. „Poprzez kult - pisze papież Franciszek w encyklice Laudato Si’ - jesteśmy zachęceni do objęcia świata na innym poziomie"32. Od najmłodszych lat trzeba więc pracować nad formowaniem cnoty religijności. W wychowaniu należy przede wszystkim zwracać uwagę na hierarchię przedmiotów kultu, by nie zaniedbywać tych, które są najważniejsze dla pełnego rozwoju życia duchowego człowieka ${ }^{33}$.

${ }^{30}$ Por. P. Góralczyk, Wyzwolenie z niewoli do wolności w Chrystusie, „Communio" 13 (1993) 5, s. 30-42.

${ }^{31}$ Por. J. Królikowski, Zrehabilitować cnotę. Poszukiwania teologicznomoralne, Tarnów 2004, s. 45-57; M. Z. Stepulak, Cnoty a rozwój moralny i religijny człowieka, „Teologiczne Studia Siedleckie” 3 (2006), s. 139-153.

32 Franciszek, Encyklika „Laudato Si”, Kraków 2015, nr 235.

33 Por. T. Zadykowicz, Kult religijny jako źródło postaw moralnych, „Teologia i Moralność" 6 (2009), s. 91-100. 
Ale trzeba sobie uświadomić, że cały proces formacji człowieka wymaga konsekwentnej realizacji i podjęcia odpowiedzialnych działań w różnych formach i przejawach życia chrześcijańskiego. Duszą życia moralnego człowieka są cnoty teologalne, czyli wiara, nadzieja i miłość. Wiara należy do fundamentalnych postaw w życiu człowieka ${ }^{34}$. Przez wiarę dokonuje się bowiem wewnętrzna przemiana człowieka, co konsekwentnie musi rzutować na całokształt jego moralnych postaw i zachowań do tego stopnia, że można stwierdzić, iż wiara, usytuowana w centrum ludzkiego życia, staje się wielkim procesem moralnego wychowania osoby, jedyną i właściwą szkołą w pełni chrześcijańskiego życia ${ }^{35}$. A „pierwszym środowiskiem, w którym wiara oświeca miasto ludzi - jak uczy papież Franciszek - jest rodzina. [...]. Dlatego jest ważne, aby rodzice dbali o wspólne praktykowanie wiary w rodzinie, towarzyszyli dojrzewaniu wiary dzieci”36.

$\mathrm{Z}$ kolei cnota nadziei odpowiednio kształtowana pomaga człowiekowi określić granice ludzkiego zaangażowania w sprawy doczesne i wspiera $\mathrm{w}$ dojrzewaniu na ostateczne spotkanie $\mathrm{z}$ Chrystusem ${ }^{37}$. Stoi zatem u podstaw ludzkich odniesień do świata jak i do rzeczy ostatecznych. Pełni ważną rolę w kształtowaniu hierarchii wartości. Praktykowanie nadziei ma istotny wpływ na całe życie moralne chrześcijanina, tworząc nowego człowieka na podobieństwo Chrystusa ${ }^{38}$. Słuszne jest więc twierdzenie papieża Benedykta, że „kto ma nadzieję, żyje inaczej” ${ }^{39}$.

Życie moralne człowieka kształtowane mocną wiarą i niezachwianą nadzieją wypowiada się szczególnie przez miłość, „która - zdaniem Bene-

${ }^{34}$ Por. F. Greniuk, Wiara w postawie moralnej człowieka, w: Wiara w postawie ludzkiej. Homo meditans VI, red. W. Słomka, Lublin 1991, s. 123.

35 Por. szerzej: LF 37-55. Por. także: Benedykt XVI, List apostolski „Porta fidei”, Kraków 2012, nr 6-15.

${ }^{36}$ LF 52-53. Por. także: Benedykt XVI, Rodzino, żyj i przekazuj wiarę! Przemówienie przed modlitwą Anioł Pański (Watykan - 2 lipca 2006), „Sprawy Rodziny” 4 (2006), s. 11.

37 Por. Benedykt XVI, Nieście wszystkim Chrystusa, nadzieję świata. Homilia podczas IV Krajowego Kongresu Kościelnego we Włoszech (Werona - 19 października 2006), „L'Osservatore Romano” (wyd. pol.) 28 (2007) 1, s. 33.

38 Por. A. Murawska, Nadzieja jako wartość w wychowaniu, w: Wychowanie moralne w szkole katolickiej, red. A. Sowiński, A. Dymer, Szczecin 2003, s. 299-307. Por. także: K. Misiaszek, O nadziei w wychowaniu, „Studia Bobolanum” 3 (2009), s. 33-42.

39 Benedykt XVI, Encyklika „Spe salvi”, Tarnów 2007, nr 2 (dalej: SS). 
dykta - stanowi zasadniczą siłę napędową prawdziwego rozwoju każdego człowieka" ${ }^{40}$. Dlatego formacja moralna ma prowadzić do ukształtowania w człowieku dojrzałej miłości Boga i bliźniego ${ }^{41}$. Trzeba jednak pamiętać, że „obie te miłości czerpią życie z miłości pochodzącej od Boga, który pierwszy nas umiłował" ${ }^{\prime 2}$. Dlatego też w pracy formacyjnej najistotniejsze będzie najpierw zawsze to, by człowiek umiał odkryć i przyjąć miłość Boga jako dar, by umiał w duchu dziecięcej ufności przyjąć miłość, którą został obdarowany. Taki człowiek, który odkryje i przyjmie miłość Boga będzie też zdolny do prawdziwej miłości ludzi, nawet nieprzyjaciół ${ }^{43}$. Miłość ta znajdzie swoje urzeczywistnienie w konkretnych czynach.

Tak więc całe życie chrześcijańskie można ująć jako życie wiary, nadziei i miłości. Odpowiedzialnymi za kształtowanie wiary nadziei i miłości u dzieci i młodzieży są przede wszystkim rodzice. Oni są dla swoich dzieci pierwszymi nauczycielami cnót i nikt ich w tym nie może zastąpić. „Rodzina - jaki uczył Jan Paweł II - strzeże, zachowuje i przekazuje cnoty oraz wartości”44.

Formacja moralna człowieka nie wyczerpuje się w cnocie religijności i cnotach teologalnych. Dojrzałość moralna wyraża się także w rozwijaniu w sobie cnót moralnych. Cnoty moralne pomagają człowiekowi spełniać dobre czyny wytrwale, skutecznie i z satysfakcją. Owe cnoty sprawiają, że człowiek jest pozytywnie ukierunkowany na przyszłość. Dlatego formowanie tych sprawności powinno być fundamentalnym zadaniem wychowania moralnego człowieka ${ }^{45}$. Z pośród wszystkich cnót moralnych fundamentalne znaczenie mają cztery sprawności: roztropność,

40 Benedykt XVI, Encyklika „Caritas in veritate”, Tarnów 2009, nr 1 (dalej: CiV).

${ }^{41}$ Por. W. Pasierbek, Duchowa formacja człowieka wyzwaniem dla humanizmu XXI wieku, w: Człowiek w jednoczacej się Europie, red. A. Królikowska, Kraków 2004, s. $65-75$.

${ }^{42}$ Por. Benedykt XVI, Encyklika „Deus caritas est”, Kraków 2006, nr 18 (dalej: DCE).

${ }^{43}$ Por. tamże, nr 18. Por. także: Benedykt XVI, Miłość jest dobrem, które każdy człowiek musi pomnażać. Przemówienie podczas Modlitwy Maryjnej z Papieżem (Watykan 13.11.2011), „L'Osservatore Romano” 33 (2012) 1, s. 54-55.

44 FC 43.

45 Por. szerzej: D. Zalewski, Wychować człowieka szlachetnego, Lublin 2006; M. J. Kempys, Rola cnót moralnych $w$ dążeniu ku petni człowieczeństwa $w$ świetle pism o. Jacka Woronieckiego, Kraków 2005. 
sprawiedliwość umiarkowanie i męstwo, zwane od św. Ambrożego kardynalnymi (od łac. cardo - zawias), jako że od ich realizacji zależy charakter człowieka. Są one podstawami na których oparte jest całe życie moralne chrześcijanina. Człowiek zdobywa te sprawności przez odpowiednie wychowanie i samowychowanie, świadome czyny i wytrwałość w wysiłku. Łaska Boża oczyszcza je i podnosi.

Formacja moralna człowieka przez cnotę religijności oraz cnoty teologalne i kardynalne domaga się jednak dopełnienia o to wszystko, co wyznacza sakramentalną drogę życia chrześcijańskiego. A zatem niezwykle ważna jest formacja sakramentalna. Papież Franciszek w Lumen fidei zauważa, że rozbudzenie wiary łączy się z rozbudzeniem sakramentalnego sensu życia człowieka i egzystencji chrześcijanina"46. Bogactwo sakramentów pozwala objąć wszystkie etapy i istotne momenty życia człowieka: narodzenie, rozwój, uzdrowienie i dar posłania. Początek życia chrześcijańskiego jest związany z sakramentem chrztu świętego. Chrzest jest „bramą” do chrześcijaństwa i duchowym fundamentem życia wyznawców Chrystusa ${ }^{47}$. Dopełnieniem konsekracji chrzcielnej jest bierzmowanie, nazywane sakramentem Ducha Świętego. Zadaniem bierzmowania jest pogłębienie wiary związanej z chrztem i uczynienie osoby bierzmowanej dojrzałym chrześcijaninem ${ }^{48}$. Z kolei w Eucharystii chrześcijanin zostaje wzmocniony pokarmem życia wiecznego. W związku z tym Benedykt XVI postuluje, by „W formacji katechetycznej dzieci, w szczególności $\mathrm{w}$ ramach przygotowania do pierwszej Komunii św., były one wprowadzane w znaczenie i piękno dotrzymywania towarzystwa Jezusowi i by było kultywowane ich zdumienie wobec Jego obecności w Eucharystii” ${ }^{4}$.

46 LF 40.

47 Por. J. Nagórny, Chrzest - nowe życie w moralności Nowego Przymierza, w: Chrzest - nowość życia. Homo meditans X, red. A. J. Nowak, W. Słomka, Lublin 1992, s. $125-135$.

${ }^{48}$ Por. J. Królikowski, Umocnienie i dopetnienie chrztu. Z teologii bierzmowania jako sakramentu wtajemniczenia chrześcijańskiego, w: Dzisiejszy bierzmowany. Problemy i wyzwania, red. J. Stala Kielce 2005, s. 44-45. Por. także: M. Słowik, Rodzina wspólnota religijno-moralna, Niepokalanów 1997, s. 82-90.

${ }_{49}$ Benedykt XVI, Adhortacja apostolska „Sacramentum caritatis”, Tarnów 2007, nr 67 (dalej: SC). Por. także: S. Suwiński, Wychowanie dziecka do życia Eucharystia, „Ateneum Kapłańskie” 584 (2006), t. 147, s. 61-72. 
Te trzy sakramenty tworzą wewnętrzną jedność i stanowią podstawowy depozyt życia i powołania chrześcijańskiego. Odpowiednie warunki dla rozwoju łask płynących z sakramentów wtajemniczenia chrześcijańskiego stwarza wspólnota rodzinna i parafialna. Te dwie komórki poprzez odpowiednią formację przyczyniają się do wzrostu życia moralno-duchowego człowieka i jego właściwych zachowań moralnych ${ }^{50}$.

Proces formacji chrześcijańskiej rozpoczęty w sakramencie chrztu, dopełniony przez bierzmowanie oraz umocniony Eucharystią jest kontynuowany w sakramencie pokuty i namaszczenia chorych. Człowiek, ulegając słabościom i grzechom, potrzebuje wybawienia. Przystępując do sakramentu pokuty, uzyskuje przebaczenie. Poprzez ten dar człowiek jedna się z Bogiem, z samym sobą i z całym Kościołem. To, co człowiek przez grzech traci, odzyskuje w sakramencie pokuty i pojednania. Stąd ważnym zadaniem - uświadamia Benedykt - „jest promowanie [...] zdecydowanego przywracania form wychowawczych wiodących do nawrócenia" ${ }^{51}$. Podobnie przez sakrament namaszczenia Bóg łaską Ducha Świętego pomaga człowiekowi: odpuszcza grzechy, zbawia, pociesza, podnosi na duchu i jeśli jest Jego wolą przywraca zdrowie. Sakrament namaszczenia jest więc źródłem uświęcenia dla człowieka chorego i źródłem łaski dla całego Kościoła ${ }^{52}$.

W chrześcijańskiej formacji moralnej ma swój niezastąpiony udział również sakrament kapłaństwa i małżeństwa. „Przyjmujący sakrament święceń są konsekrowani, by w imię Chrystusa „karmili Kościół słowem i łaską Bożą" ${ }^{53}$. Kapłaństwo sakramentalne ma więc charakter służebny. Jest darem dla wspólnoty ${ }^{54}$ Z kolei sakrament małżeństwa zobowiązuje

${ }^{50}$ Por. SC 18-19.

${ }^{51}$ SC 21. Por. W. Rzepa, Nawrócenie jako droga chrześcijańskiej formacji, w: Formacja moralna, formacja sumienia, s. 211-223.

${ }_{52}$ Por. A. Skreczko, Wychowanie do przeżywania cierpienia, „Paedagogia Christiana” 17 (2006) 1, s. 181-193.

53 KKK 1535.

54 Por. Jan Paweł II, Kapłaństwo służebne. List do kapłanów na Wielki Czwartek (Rzym - 8 kwietnia 1979), w: tenże, Listy Ojca Świętego Jana Pawła II do wszystkich kapłanów Kościoła na Wielki Czwartek (1979-1997), red. D. Greggio, Kraków 1998, s. 17. Por. także: J. Buxakowski, Permanentna formacja kapłanów, „Ateneum Kapłańskie” 505 (1993), t. 85 , s. $442-452$. 
mężczyznę i kobietę, by dzień po dniu tworzyli ze sobą wspólnotę życia i miłości, skierowaną ze swej natury na dobro małżonków oraz do zrodzenia i wychowania potomstwa ${ }^{55}$. Sakramenty służące wspólnocie i posłaniu wiernych są więc nastawione na zbawienie innych ludzi. „Przez służbę innym przyczyniają się też do zbawienia osobistego. Udzielają one szczególnego posłania w Kościele i służą budowaniu Ludu Bożego" ${ }^{56}$. W takiej perspektywie akcent pada na imperatyw moralny zawarty w sakramentach, a życie moralne chrześcijanina przybiera styl życia sakramentalnego. Trzeba jednak pamiętać, że to wszystko wymaga autentycznej i solidnej formacji. Tylko bowiem autentyczna i solidna formacja, prowadzona w szczególności przez rodzinę i Kościół, może sprawić, że chrześcijanin będzie uczestniczył w sposób świadomy w istocie i posłannictwie Boga, przyjmując sakramentalny styl życia, wypływający z celebracji sakramentów i pobudzający do urzeczywistniania w społeczeństwie wartości ewangelicznych ${ }^{57}$.

Wierząc w odradzającą i uświęcającą moc sakramentów świętych, chrześcijan nie może zapomnieć o innych płaszczyznach, które są mu konieczne do osiągnięcia dojrzałości moralnej. Jedną z istotnych płaszczyzn jest szeroko rozumiane życie społeczne. W integralnym rozwoju chrześcijańskiego życia moralnego formacja społeczna pełni bardzo ważną rolę. Płaszczyzna społeczna, obok wszystkich dotąd omówionych wymiarów życia ludzkiego, jest jednym z istotnych aspektów powołania chrześcijańskiego.

W całokształcie problematyki społecznej, można odnaleźć pewne zagadnienia o kluczowym znaczeniu dla formacji moralnej człowieka. Do najważniejszych płaszczyzn społecznych należy zaliczyć rodzinę, Kościól, pracę, kulturę i politykę. Te wszystkie szczególne płaszczyzny odpowiedzialności za życie społeczne, pełnią fundamentalną rolę w formacji człowieka, albowiem prawidłowo kształtują osobowość. Organizują i zabezpieczają społeczne życie człowieka i nadają właściwy kierunek całej jego działalności. Pozwalają mu więc w ten sposób osiągnąć pełne

${ }^{55}$ Por. Sobór Watykański II, Konstytucja duszpasterska o Kościele w świecie współczesnym „Gaudium et spes”, w: Sobór Watykański II, Konstytucje, nr 50.

${ }^{56}$ KKK 1534.

57 Por. S. Głaz, Rola rodziny w wychowaniu młodego człowieka do życia sakramentalnego, „Ateneum Kapłańskie” 611 (2011), t. 156, s. 117-130. 
człowieczeństwo i moralną doskonałość. Jednym słowem rodzina, Kościół, praca i kultura czynią życie człowieka bardziej szczęśliwym.

W świetle katolickiej nauki społecznej podstawową wartością dla człowieka jest rodzina. Jest ona najwłaściwszym środowiskiem życia i urzeczywistniania się osoby. „Rodzina - jak podkreśla papież Franciszek we wspomnianej encyklice Laudato Si' - jest miejscem formacji integralnej, w którym rozgrywają się ściśle ze sobą powiązane różne aspekty osobistego dojrzewania"58. Znaczący udział w dziele formacji człowieka do życia społecznego ma też Kościół. Zadaniem Kościoła jest pracować nad tym, aby uczynić człowieka zdolnym do „należytego kształtowania całego porządku rzeczy doczesnych i skierowania go przez Chrystusa do Boga" ${ }^{\prime 2}$. Należy przy tym podkreślić potrzebę formacji poszczególnych stanów Kościoła: kapłanów, osób konsekrowanych i ludzi świeckich, którzy ponoszą wielką odpowiedzialność za społeczny kształt życia człowieka ${ }^{60}$.

Kościół jako wspólnota wychowująca przyczynia się też do kształtowania duchowości ludzkiej pracy. Praca stanowi podstawę życia człowieka. Poprzez pracę człowiek staje się pełniej człowiekiem, staje się doskonalszy. Praca wiąże się więc z moralną odpowiedzialnością. Troską wszystkich instytucji powinna być zatem edukacja przygotowująca do zadań wynikających ze społecznego podziału pracy, kształcenie wiedzy i umiejętności wraz z kształtowaniem postaw moralnych ${ }^{61}$. Tożsamość człowieka realizuje się także w dziedzinie kultury. Dlatego potrzebna jest zarówno formacja do kultury jak i przez kulturę. W tym procesie chodzi w istocie o to, aby wychować człowieka do mądrego korzystania z kultury, do rozróżniania destrukcyjnych i konstruktywnych elementów kultury, oraz by

58 Franciszek, Encyklika „Laudato Si”, nr 213. Por. także: P. Kieniewicz, Wychowanie społeczne w świetle „Familiaris consortio”, w: Wychowanie w rodzinie, s. 75-85.

59 Sobór Watykański II, Dekret o apostolstwie świeckich „Apostolicam actuositatem", w: Sobór Watykański II, Konstytucje, nr 7.

${ }^{60}$ Por. M. Lukoszek, Tożsamość kapłana i jego postawa wobec świata w nauczaniu Jana Pawła II, „Horyzonty Wychowania” 9 (2010), s. 188-203; T. Paszkowska, Dojrzałość chrześcijańska w postawie zakonnej, w: Dojrzałość chrześcijańska. Homo meditans XI, red. A. J. Nowak, W. Słomka, Lublin 1994, s. 77-105; D. Stankiewicz, Duchowa formacja świeckich do apostolstwa w funkcji kapłańskiej, „Studia Warmińskie” 38 (2002), s. 395-405.

${ }^{61}$ Por. Jan Paweł II, Encyklika „Laborem exercens”, Poznań-Warszawa 1981, nr 10. Por. także: A. Solak, Wychowanie chrześcijańskie i praca ludzka. Studium współzależności, Warszawa 2004, s. 110. 
mógł tworzyć kulturę opartą na wartościach wyższych ${ }^{62}$. To one bowiem decydują o formacie człowieka oraz o jakości życia społecznego. Proces wychowania powinien finalizować się w procesie samowychowania. Ten ostatni jest jednak możliwy tylko wówczas, kiedy wychowanek uformuje w sobie „aksjologiczne wnętrze" 63 .

Nie można też mówić o dojrzałości moralnej bez ukształtowania w człowieku ducha patriotyzmu. Patriotyzm jako postawa jest miłością ojczyzny. A ponieważ o pojęciu ojczyzny stanowi wiele elementów, dlatego patriotyzm jest po prostu miłością i szacunkiem wszystkich tych wyznaczników, które konstytuują pojęcie ojczyzny. Formacja patriotyczna jako część formacji społecznej prowadzona zwłaszcza w środowisku rodzinnym i szkolnym ma wskazywać drogę brania na siebie odpowiedzialności za dobro jakim jest kraj ojczysty ${ }^{64}$.

$\mathrm{Ku}$ dobru człowieka i ojczyzny ma być skierowana także cała działalność polityczna. „Polityka - jak uczy papież Franciszek - jest powołaniem wzniosłym, jest jedną z najcenniejszych form miłości, ponieważ szuka dobra wspólnego" ${ }^{\prime \prime}$. Jeżeli polityka nie służy człowiekowi i społeczeństwu, ale staje się celem sama dla siebie, nie tylko traci rację bytu, ale nawet, może stać się źródłem alienacji. Zadaniem polityki jest troska o prawdziwą demokrację ${ }^{66}$. W tej perspektywie istnieje konieczność formowania człowieka do podjęcia odpowiedzialnej obecności we współczesnym życiu politycznym, zwłaszcza, gdy obecność ta ma być naznaczona

${ }^{62}$ Por. F. Adamski, Integralna wizja kultury u podstaw chrześcijańskiego wychowania, w: Wychowanie chrześcijańskie a kultura, red. M. Nowak, T. Ożóg, Lublin 2000, s. 15-20; W. Kawecki, Potrzeba edukacji kulturowej, „Studia Redemptorystowskie” 7 (2009), s. $128-140$.

${ }^{63}$ Por. szerzej: Benedykt XVI, Adhortacja apostolska „Verbum Domini”, Kraków 2010, nr 109-116.

${ }^{64}$ Por. szerzej: J. Nagórny, Wychowanie do patriotyzmu $w$ nauczaniu Jana Pawła II, w: Formacja moralna, formacja sumienia, s. 129-151; K. Chałas, S. Kowalczyk, Wychowanie ku wartościom narodowo-patriotycznym, t. 2: Naród. Ojczyzna. Patriotyzm. Państwo. Pokój, Lublin-Kielce 2006.

${ }^{65}$ Franciszek, Adhortacja apostolska „Evangelii gaudium”, Kraków 2013, nr 205.

${ }^{66}$ Por. Jan Paweł II, Encyklika „Sollicitudo rei socialis”, Wrocław 1987, nr 33. Por. także: tenże, Demokracja i wartości. Przestanie do uczestników VI Sesji Plenarnej Papieskiej Akademii Nauk Społecznych (Watykan - 23 lutego 2000), „L'Osservatore Romano” (wyd. pol.) 21 (2000) 6, s. 4. 
wniesieniem w ten świat wartości chrześcijańskich ${ }^{67}$. Formacja polityczna jest niezwykle ważnym wyznacznikiem świadomości społecznej. Formacja ta powinna objąć zarówno wykształcenie polityczne, jak i odpowiednie ukształtowanie sumienia i postaw osobowych ${ }^{68}$.

Widać zatem, że te wszystkie płaszczyzny odpowiedzialności za życie społeczne wyraźnie łączą się ze sobą. Mają bowiem zawsze swoje odniesienie do człowieka. Co więcej, nie chodzi tylko o fakt, że człowiek „wpisany” jest $\mathrm{w}$ życie społeczne i że wszystkie zachodzące $\mathrm{w}$ nim procesy dotyczą człowieka. Osoba ludzka jest po prostu ostatecznym i podstawowym podmiotem tegoż życia. Oznacza to, iż struktury życia społecznego muszą być tworzone na miarę człowieka jako osoby i jego moralnego doskonalenia się.

\section{WNIOSKI}

W świetle powyższych refleksji należy stwierdzić, że opracowanie klarownego i w pełni realistycznego modelu formacji moralnej człowieka byłby adekwatną odpowiedzią na te problemy i wyzwania, które niesie w sobie rzeczywistość ludzkiego życia podlegająca ciągłym przeobrażeniom i kulturowym fluktuacjom. Jakkolwiek formacja moralna jest rzeczywistością dynamiczną, każde nowe spojrzenie na nią musi uwzględniać pewne elementy stałe, wynikające $z$ doktryny Kościoła, aby nie doszło do zmian w zakresie istoty czy natury chrześcijańskiej myśli wychowawczej. Każda formacja moralna powinna być oparta na teologicznych prawdach o stworzeniu, odkupieniu i uświęceniu człowieka. Determinują one jej główny kierunek, ale też znacząco wpływają na dobór środków i metod. Niewątpliwie przyjęcie Chrystusa i tego, co od Niego pochodzi, czyni sam proces formacji łatwiejszym i skuteczniejszym. Daje stabilny fundament i pozwala dowartościować wszystko co składa się na ludzką egzystencję. Z kolei pamięć Chrystusa, o którą szczególnie powinno chodzić w formacji moralnej, pozwala zachować tożsamość osoby, rodzi świadomość powołania i jest źródłem jedności. Ta zaś uobecnia się i wyraża we

${ }^{67}$ Por. szerzej: A. Derdziuk, Świadectwo wartości w polityce, „Forum Teologiczne" 11 (2010), s. 35-50.

${ }_{68}$ Por. J. Wróbel, Prymat racji moralnych $w$ życiu politycznym, „Roczniki Teologiczne" 38-39 (1991-1992) 3, s. 25-43. 
wspólnotowości i łączności z prawowitym autorytetem kościelnym. Pójście z Kościołem drogą wiary w Chrystusa pozwala człowiekowi być tym, kim być może i kim być powinien.

Trzeba jednocześnie dodać, że kwestia formacji moralnej wpisuje się w otwartą dyskusję i domaga się dalszych badań. Można więc żywić nadzieję, że przedłożone w niniejszej publikacji refleksje, staną się swego rodzaju zaproszeniem do bardziej szczegółowego studium omówionych problemów, a przez to ukażą, jak wielkie i ważne zadania stoją wciąż nie tylko przed teologią moralną czy teologią duchowości, ale także przed psychologią, pedagogiką, katechetyką i innymi gałęziami wiedzy nastawione na formację człowieka. Nie sposób przecenić znaczenia tej formacji nie tylko w teraźniejszym, ale też przyszłym życiu człowieka tak w jego wymiarze jednostkowym, jak i wspólnotowym.

Streszczenie. Chrześcijańska formacja moralna wzorcem etycznym dla współczesnego człowieka. Do integralnego rozwoju człowiek potrzebuje jasnej orientacji moralnej w życiu, wyraźnego sprecyzowania celu i sensu egzystencji oraz ustalenia właściwej postawy. Niestety, w dzisiejszym świecie ten aspekt rozwoju człowieka jest wyraźnie lekceważony. Stąd istnieje konieczność opracowania klarownego i w pełni realistycznego modelu formacji moralnej człowieka, który byłby adekwatną odpowiedzią na te problemy i wyzwania, które niesie w sobie rzeczywistość ludzkiego życia. Taki też cel przyświeca autorowi niniejszej publikacji. Chodzi o to, aby człowiek w swoich wyborach życiowych zdobył umiejętność rozróżniana dobra od zła i osiągnął zdolność dojrzałego i odpowiedzialnego działania.

Słowa kluczowe: człowiek; życie ludzkie; chrześcijańska formacja moralna; rodzina; szkoła; Kościół.

Abstract. Christian moral formation as an ethical standard for the modern man. The integral development of the human being needs a clear moral orientation in life, an explicit purpose and meaning of existence and determination of the appropriate attitude. Unfortunately, in today's world, this aspect of human development is clearly underestimated. Hence there is a need to develop a clear and fully realistic model of moral formation of man that would be an adequate response to these problems and challenges, which the reality of human life carries. It is also the goal of the author of this publication. The idea is for a man to gain the ability to tell right from wrong in his life choices and to achieve the ability to take a mature and responsible action.

Keywords: man; human life; Christian moral formation; family; school; church. 


\section{BIBLIOGRAFIA}

Adamski F., Integralna wizja kultury u podstaw chrześcijańskiego wychowania, w: Wychowanie chrześcijańskie a kultura, red. M. Nowak, T. Ożóg, Lublin 2000, s. 15-20.

Adrjanek R., Wychowanie moralne dzieci i młodzieży jako zadanie rodziny, szkoły $i$ Kościoła $w$ świetle nauczania Jana Pawła II, „Sosnowieckie Studia Teologiczne” 7 (2005), s. 9-24.

Benedykt XVI, Adhortacja apostolska „Sacramentum caritatis”, Tarnów 2007.

Benedykt XVI, Adhortacja apostolska „Verbum Domini”, Kraków 2010.

Benedykt XVI, Encyklika „Caritas in veritate”, Tarnów 2009.

Benedykt XVI, Encyklika „Deus caritas est”, Kraków 2006.

Benedykt XVI, Encyklika „Spe salvi”, Tarnów 2007.

Benedykt XVI, List apostolski „Porta fidei”, Kraków 2012.

Benedykt XVI, Miłość jest dobrem, które każdy człowiek musi pomnażać. Przemówienie podczas Modlitwy Maryjnej z Papieżem (Watykan - 13.11.2011), „L'Osservatore Romano" 33 (2012) 1, s. 54-55.

Benedykt XVI, Nieście wszystkim Chrystusa, nadzieję świata. Homilia podczas IV Krajowego Kongresu Kościelnego we Włoszech (Werona - 19 października 2006), „L'Osservatore Romano” (wyd. pol.) 28 (2007) 1, s. 31-33.

Benedykt XVI, Rodzina, szkoła, parafia - miejsca formacji chrześcijanina. Homilia podczas nieszporów (Monachium - 10 września 2006), „Sprawy Rodziny” 1 (2007), s. $10-14$.

Benedykt XVI, Rodzino, żyj i przekazuj wiarę! Przemówienie przed modlitwa Anioł Pański (Watykan - 2 lipca 2006), „Sprawy Rodziny” 4 (2006), s. 10-11.

Benedykt XVI, Uczmy się przeżywać z Chrystusem cierpienia życia duszpasterskiego. "Lectio divina” dla duchowieństwa diecezji rzymskiej (Watykan - 18 lutego 2010), „L'Osservatore Romano” (wyd. pol.) 31 (2010) 5, s. 24-28.

Bławat A., Formacja seksualna, w: Słownik małżeństwa i rodziny, red. E. Ozorowski, Warszawa-Łomianki 1999, s. 150.

Borutka T., Stała formacja obowiązkiem każdego człowieka wierzacego, „Polonia Sacra” 2 (1999) 4, s. 15-31.

Buxakowski J., Permanentna formacja kapłanów, „Ateneum Kapłańskie” 505 (1993), t. 85 , s. $442-452$.

Chałas K., Kowalczyk S., Wychowanie ku wartościom narodowo-patriotycznym, t. II. Naród. Ojczyzna. Patriotyzm. Państwo. Pokój, Lublin-Kielce 2006.

Chlewiński Z., Formacja, w: Encyklopedia Katolicka, t. 5, red. L. Bieńkowski, P. Hemperek, S. Kamiński i in., Lublin 1989, kol. 389.

Derdziuk A., Formacja moralna a formacja sumienia, w: Formacja moralna, formacja sumienia, red. J. Nagórny, T. Zadykowicz, Lublin 2006, s. 13-32

Derdziuk A., Świadectwo wartości w polityce, „Forum Teologiczne” 11 (2010), s. 35-50. Franciszek, Adhortacja apostolska „Evangelii gaudium”, Kraków 2013. 
Franciszek, Encyklika „Laudato Si’ ”, Kraków 2015.

Franciszek, Encyklika „Lumen fidei”, Kraków 2013.

Glombik K., Współczesny kontekst społeczno-kulturowy wychowania seksualnego. Próba diagnozy, „Family Forum” 1 (2011), s. 155-177.

Głaz S., Rola rodziny w wychowaniu młodego człowieka do życia sakramentalnego, „Ateneum Kapłańskie” 611 (2011), t. 156, s. 117-130.

Góralczyk P., Jezus Chrystus norma moralności chrześcijańskiej, „Communio” 27 (1997) 2, s. 101-113.

Góralczyk P., Wyzwolenie z niewoli do wolności w Chrystusie, „Communio” 13 (1993) 5, s. 30-42.

Greniuk F., Wiara $w$ postawie moralnej człowieka, w: Wiara $w$ postawie ludzkiej. Homo meditans VI, red. W. Słomka, Lublin 1991, s. 115-130.

Jakubiec M., Rola rodziny w ksztattowaniu sumienia dziecka, w: Wychowanie $w$ rodzinie, red. F. Adamski, Kraków 2010, s. 151-173.

Jan Paweł II, Demokracja i wartości. Przesłanie do uczestników VI Sesji Plenarnej Papieskiej Akademii Nauk Społecznych (Watykan - 23 lutego 2000), „L'Osservatore Romano” (wyd. pol.) 21 (2000) 6, s. 4-5.

Jan Paweł II, Adhortacja apostolska „Christifideles laici”, Wrocław 1989.

Jan Paweł II, Adhortacja apostolska „Ecclesia in Europa”, Wrocław 2003.

Jan Paweł II, Adhortacja apostolska „Familiaris consortio”, Częstochowa 1991.

Jan Paweł II, Adhortacja apostolska „Pastores dabo vobis”, Wrocław 1995.

Jan Paweł II, Encyklika „Laborem exercens”, Poznań-Warszawa 1981.

Jan Paweł II, Encyklika „Sollicitudo rei socialis”, Wrocław 1987.

Jan Paweł II, Encyklika „Veritatis splendor”, Wrocław 1993.

Jan Paweł II, Kapłaństwo służebne. List do kapłanów na Wielki Czwartek (Rzym - 8 kwietnia 1979), w: tenże, Listy Ojca Świętego Jana Pawła II do wszystkich kapłanów Kościoła na Wielki Czwartek (1979-1997), red. D. Greggio, Kraków 1998, s. 11-34.

Jan Paweł II, List do Rodzin, Wrocław 1994.

Jan Paweł II, Odpowiedzialność za prawdę poznawana i przekazywana. Przemówienie do przedstawicieli świata nauki (KUL - 9 czerwca 1987), w: tenże, Nauczanie społeczne. Trzeci pielgrzymka do Polski 8-14 czerwca 1987, Warszawa 1988, s. 27-34.

Jan Paweł II, Wychowanie człowieka do wartości moralnych. Przemówienie do uczestników XIV Światowego Kongresu Szkół Katolickich (Rzym - 5 marca 1994), „L'Osservatore Romano" (wyd. pol.) 15 (1994) 5, s. 16-17.

Jan Paweł II, Wychowanie młodego pokolenia zadaniem wszystkich. Przemówienie do uczestników europejskiego sympozjum na temat: „Wyzwania edukacji” (Rzym 3 lipca 2004), „L’Osservatore Romano” (wyd. pol.) 25 (2004) 11-12, s. 22-23.

Katechizm Kościoła Katolickiego, Poznań 1994.

Kawecki W., Potrzeba edukacji kulturowej, „Studia Redemptorystowskie” 7 (2009), s. 128-140.

Kempys M. J., Rola cnót moralnych $w$ dążeniu ku pełni człowieczeństwa $w$ świetle pism o. Jacka Woronieckiego, Kraków 2005. 
Kieniewicz P., Wychowanie społeczne $w$ świetle „Familiaris consortio”, w: Wychowanie w rodzinie, s. 75-85.

Królikowski J., Umocnienie i dopełnienie chrztu. Z teologii bierzmowania jako sakramentu wtajemniczenia chrześcijańskiego, w: Dzisiejszy bierzmowany. Problemy i wyzwania, red. J. Stala, Kielce 2005, s. 35-52.

Królikowski J., Zrehabilitować cnotę. Poszukiwania teologicznomoralne, Tarnów 2004.

Kwiek M., Błędy w wychowaniu płciowym człowieka, w: Wychowanie do czystości - utopia czy zadanie red. J. Kochel, Opole 2011, s. 145-152.

Lukoszek M., Tożsamość kapłana i jego postawa wobec świata w nauczaniu Jana Pawła II, „Horyzonty Wychowania” 9 (2010), s. 188-203

Lulek B., Wolność $i$ odpowiedzialność w procesie wychowania. Szanse i zagrożenia, w: Wolność i wychowanie, red. M. Urbańska, Tarnów 2011, s. 89-106.

Maryniarczyk A., Wolność a prawda, „Człowiek w Kulturze” 9 (1997), s. 61-71.

Misiaszek K., O nadziei w wychowaniu, „Studia Bobolanum” 3 (2009), s. 33-42.

Mojek S., Formacja moralna, w: Jan Paweł II, Encyklopedia Nauczania Moralnego, red. J. Nagórny, K. Jeżyna, Radom 2005, s. 205-209.

Mroczkowski I., Chrześcijańska koncepcja człowieka i jego działania, w: Być chrześcijaninem dziś. Teologia dla szkół średnich, red. M. Rusecki, Lublin 1992, s. 277-291.

Murawska A., Nadzieja jako wartość w wychowaniu, w: Wychowanie moralne w szkole katolickiej, red. A. Sowiński, A. Dymer, Szczecin 2003, s. 299-307.

Nagórny J., Chrzest - nowe życie w moralności Nowego Przymierza, w: Chrzest - nowość życia. Homo meditans X, red. A. J. Nowak, W. Słomka, Lublin 1992, s. 123-137.

Nagórny J., Wychowanie do patriotyzmu w nauczaniu Jana Pawła II, w: Formacja moralna, formacja sumienia, s. 129-151.

Nowicka-Kozioł M., Odpowiedzialność w świecie alternatyw współczesnego humanizmu, Warszawa 1997.

Olek-Redlarska Z., Edukacja moralna - szansą?, „Życie Szkoły” 2 (1999), s. 138-139.

Orzeszyna J., Kształtowanie sumienia podstawowym obowiazkiem człowieka, „Sosnowieckie Studia Teologiczne" 4 (1999), s. 59-74.

Orzeszyna J., Moralny aspekt ludzkiej wolności, „Analecta Cracoviensia” 33 (2001), s. $177-190$.

Papieska Rada ds. Rodziny, Ludzka płciowość: prawda i znaczenie. Wskazania dla wychowania $w$ rodzinie, Watykan 1995.

Pasierbek W., Duchowa formacja człowieka wyzwaniem dla humanizmu XXI wieku, w: Człowiek w jednoczacej się Europie, red. A. Królikowska, Kraków 2004, s. 65-75.

Paszkowska T., Dojrzałość chrześcijańska w postawie zakonnej, w: Dojrzałość chrześcijańska. Homo meditans XI, red. A. J. Nowak, W. Słomka, Lublin 1994, s. 77-105.

Reszczyńska E., Biblijne podstawy godności osoby ludzkiej, w: Wyznawać wiarę dzisiaj. Katecheza dorosłych na podstawie Katechizmu Kościoła Katolickiego, red. S. Łabendowicz, Sandomierz 1999, s. 461-467.

Rzepa W., Nawrócenie jako droga chrześcijańskiej formacji, w: Formacja moralna, formacja sumienia, s. 211-223. 
Skreczko A., Wychowanie do przeżywania cierpienia, „Paedagogia Christiana” 17 (2006) 1, s. 181-193.

Słowik M., Rodzina wspólnotą religijno-moralną, Niepokalanów 1997.

Sobór Watykański II, Deklaracja o wychowaniu chrześcijańskim „Gravissimum educationis”, w: Sobór Watykański II, Konstytucje. Dekrety. Deklaracje, Poznań 1968, s. 313-324.

Sobór Watykański II, Dekret o apostolstwie świeckich „Apostolicam actuositatem”, w: Sobór Watykański II, Konstytucje. Dekrety. Deklaracje, Poznań 1968, s. 379-405.

Sobór Watykański II, Konstytucja duszpasterska o Kościele w świecie współczesnym „Gaudium et spes”, w: Sobór Watykański II, Konstytucje. Dekrety. Deklaracje, Poznań 1968, s. 537-620.

Solak A., Wychowanie chrześcijańskie i praca ludzka. Studium współzależności, Warszawa 2004.

Stankiewicz D., Duchowa formacja świeckich do apostolstwa w funkcji kapłańskiej, „Studia Warmińskie" 38 (2002), s. 395-405.

Starnawski W., Doświadczenie prawdy i jego znaczenie w wychowaniu, w: Wychowanie chrześcijańskie. Między tradycją a współczesnością, red. A. Rynio, Lublin 2007, s. 317-330.

Stepulak M. Z., Cnoty a rozwój moralny i religijny człowieka, „Teologiczne Studia Siedleckie" 3 (2006), s. 139-153.

Suwiński S., Wychowanie dziecka do życia Eucharystią, „Ateneum Kapłańskie” 584 (2006), t. 147 , s. $61-72$.

Szymczak J. S., Problematyka wychowania ludzkiej płciowości w nauczaniu Jana Pawła II, „Studia nad Rodziną” 1 (1997) 1, s. 53-62.

Wolicki M., Wychowanie sumienia jako najistotniejszy element wychowania moralnego, w: Wychowanie chrześcijańskie. Między tradycją a współczesnością, red. A. Rynio, Lublin 2007, s. 393-405.

Wróbel J., Prymat racji moralnych $w$ życiu politycznym, „Roczniki Teologiczne” 38-39 (1991-1992) 3, s. 25-44.

Zadykowicz T., Kult religijny jako źródło postaw moralnych, „Teologia i Moralność” 6 (2009), s. 91-100.

Zalewski D., Wychować człowieka szlachetnego, Lublin 2006.

Życiński J., Wiara chrześcijańska $w$ dialogu z kultura współczesna według Jana Pawła II, „Ethos” 11 (1998) 1-2, s. 133-146. 